\title{
Transforming growth factor $\beta 1$-induced astrocyte migration is mediated in part by activating 5- lipoxygenase and cysteinyl leukotriene receptor 1
}

\author{
Xue-Qin Huang, Xia-Yan Zhang, Xiao-Rong Wang, Shu-Ying Yu, San-Hua Fang, Yun-Bi Lu, Wei-Ping Zhang \\ and Er-Qing Wei*
}

\begin{abstract}
Background: Transforming growth factor- $\beta 1$ (TGF- $\beta 1$ ) is an important regulator of cell migration and plays a role in the scarring response in injured brain. It is also reported that 5-lipoxygenase (5-LOX) and its products, cysteinyl leukotrienes (CysLTs, namely $\mathrm{LTC}_{4}, \mathrm{LTD}_{4}$ and $\mathrm{LTE}_{4}$ ), as well as cysteinyl leukotriene receptor $1\left(\mathrm{Cys}_{\mathrm{L}} \mathrm{L} \mathrm{T}_{1} \mathrm{R}\right)$ are closely associated with astrocyte proliferation and glial scar formation after brain injury. However, how these molecules act on astrocyte migration, an initial step of the scarring response, is unknown. To clarify this, we determined the roles of 5-LOX and CysLT, R in TGF- $\beta 1$-induced astrocyte migration.
\end{abstract}

Methods: In primary cultures of rat astrocytes, the effects of TGF- $\beta 1$ and CysLT receptor agonists on migration and proliferation were assayed, and the expression of 5-LOX, CysLT receptors and TGF- $\beta 1$ was detected. 5-LOX activation was analyzed by measuring its products (CysLTs) and applying its inhibitor. The role of Cys $L T_{1} R$ was investigated by applying CysLT receptor antagonists and CysLT, R knockdown by small interfering RNA (siRNA). TGF- $\beta 1$ release was assayed as well.

Results: TGF- $\beta 1$-induced astrocyte migration was potentiated by $\mathrm{LTD}_{4}$, but attenuated by the 5 -LOX inhibitor zileuton and the Cys $\mathrm{LT}_{1} R$ antagonist montelukast. The non-selective agonist $\mathrm{LTD}_{4}$ at 0.1 to $10 \mathrm{nM}$ also induced a mild migration; however, the selective agonist N-methyl-LTC $C_{4}$ and the selective antagonist Bay cysLT2 for CysLT $R$ had no effects. Moreover, CysLT,R siRNA inhibited TGF- $\beta 1$ - and $L_{1} D_{4}$-induced astrocyte migration by downregulating the expression of this receptor. However, TGF- $\beta 1$ and $\mathrm{LTD}_{4}$ at various concentrations did not affect astrocyte proliferation $24 \mathrm{~h}$ after exposure. On the other hand, TGF- $\beta 1$ increased 5-LOX expression and the

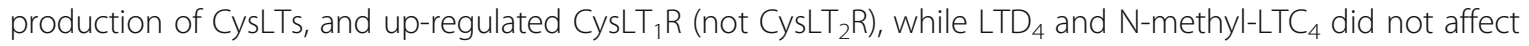
TGF- $\beta 1$ expression and release.

Conclusions: TGF- $\beta 1$-induced astrocyte migration is, at least in part, mediated by enhanced endogenous CysLTs through activating Cys $L T_{1} R$. These findings indicate that the interaction between the cytokine TGF- $\beta 1$ and the pro-inflammatory mediators CysLTs in the regulation of astrocyte function is relevant to glial scar formation.

Keywords: Transforming growth factor- $\beta 1$, Cysteinyl leukotriene, Cysteinyl leukotriene receptor, 5-lipoxygenase, Astrocyte, migration, Glial scar

\footnotetext{
* Correspondence: weieq2006@zju.edu.cn

Department of Pharmacology, Key Laboratory of Medical Neurobiology of Ministry of Health of China, Zhejiang Province Key Laboratory of Neurobiology, Zhejiang University School of Medicine, 866 Yuhangtang Road, Hangzhou 310058, China
}

\section{() Biomed Central}

(c) 2012 Huang et al.; licensee BioMed Central Ltd. This is an Open Access article distributed under the terms of the Creative Commons Attribution License (http://creativecommons.org/licenses/by/2.0), which permits unrestricted use, distribution, and reproduction in any medium, provided the original work is properly cited. 


\section{Background}

Glial scar formation is a critical event in repair responses after injury of the central nervous system (CNS) [1,2]. The glial scar is a complex of cellular components and mainly consists of reactive astrocytes (undergoing proliferation and morphological changes). Following focal CNS injury, reactive astrocytes migrate towards the lesion and then organize into a densely packed glial scar $[1,2]$. As the key step of glial scar formation, astrocyte migration is regulated by various factors [3-5], among which transforming growth factor- $\beta$ (TGF- $\beta$ ) is known as an important regulator $[5,6]$.

TGF- $\beta$, a family of multifunctional cytokines, regulates a broad diversity of physiological and pathological processes, including wound healing, inflammation, cell proliferation, differentiation, migration and extracellular matrix synthesis [7-10]. TGF- $\beta 1$ is an important mediator in the pathogenesis of several disorders in the CNS, such as in the organization of a glial scar in response to injury and in several neurodegenerative disorders $[7,11,12]$. After CNS injury, elevated TGF- $\beta$ levels in astrocytes have been shown to induce astrocytic scar formation [13], and are also associated with ischemic brain injury $[14,15]$.

On the other hand, cysteinyl leukotrienes (CysLTs, namely $\mathrm{LTC}_{4}, \mathrm{LTD}_{4}$, and $\mathrm{LTE}_{4}$ ), the 5-lipoxygenase (5LOX, EC 1.13.11.34) metabolites of arachidonic acid [16], are bioactive lipid mediators that modulate immune and inflammatory responses [16-19] through activating their receptors, CysLT $_{1} \mathrm{R}$ and $\mathrm{CysLT}_{2} \mathrm{R}[17,20,21]$. In the rat brain, 5-LOX is activated and the production of CysLTs is enhanced after focal cerebral ischemia, resulting in neuronal injury and astrocyte proliferation (astrocytosis). This post-ischemic astrocytosis is associated with up-regulated $\mathrm{CysLT}_{1} \mathrm{R}$ and $\mathrm{CysLT}_{2} \mathrm{R}$ [22-26]. The CysLT $_{1} R$ antagonist pranlukast attenuates postischemic astrocytosis and glial scar formation in the chronic phases of focal cerebral ischemia in mice and rats $[25,27,28]$. This effect suggests that $\mathrm{CysLT}_{1} \mathrm{R}$ mediates CysLT-induced astrocytosis and glial scar formation in response to in vivo ischemic injury. In primary astrocyte cultures, CysLTs are released after oxygen-glucose deprivation-induced ischemic injury, and the resultant activation of $\mathrm{CysLT}_{1} \mathrm{R}$ mediates astrocyte proliferation $[29,30]$. These findings imply that the endogenously released CysLTs might play an autocrine role in the induction of astrocytosis and resultant glial scar formation through activating $\mathrm{CysLT}_{1} \mathrm{R}$.

However, whether $\mathrm{CysLT}_{1} \mathrm{R}$ mediates astrocyte migration in the process of glial scar formation needs investigation. In the periphery, $\operatorname{CysLT}_{1} \mathrm{R}$ mediates migration in many types of cells, such as monocytes [31], dendritic cells [32], monocyte-derived dendritic cells [33], vascular smooth muscle cells [34], intestinal epithelial cells [35] and endothelial cells [31,34-36]. Therefore, CysLT $_{1} \mathrm{R}$ may also be an inducer of astrocyte migration, but many other factors have been reported to be potent inducers, such as TGF- $\beta 1[37,38]$. Thus, there may be interactions between $\mathrm{CysLT}_{1} \mathrm{R}$ and other regulators (for example, TGF- $\beta 1)$. TGF- $\beta 1$ up-regulates CysLT $_{1} R$ expression and increases the production of CysLTs in several cell types such as hepatic stellate cells [39] and bronchial smooth muscle cells [37]. Based on these findings, it is possible that the regulatory role of TGF- $\beta 1$ in astrocyte migration may be mediated by enhanced production of CysLTs via CysLT $_{1} \mathrm{R}$ activation. To clarify this possibility, in the present study, we investigated the interactions between TGF- $\beta 1$ and 5-LOX/CysLT 1 R in astrocyte migration.

\section{Methods}

\section{Primary cultures of rat astrocytes}

Primary astrocytes were isolated from the cerebral cortex of newborn Sprague-Dawley rats within $24 \mathrm{~h}$ as described previously [30,40]. In brief, the cortices were digested with $0.25 \%$ trypsin and plated into poly-L-lysine-coated flasks. Cells were cultured in highglucose DMEM (Gibco, Grand Island, NY, USA) supplemented with $10 \%$ fetal bovine serum (FBS), $2 \mathrm{mM}$ glutamine, 100 units $/ \mathrm{mL}$ penicillin and $100 \mu \mathrm{g} / \mathrm{mL}$ streptomycin at $37^{\circ} \mathrm{C}$ in a humidified atmosphere of $95 \%$ air $/ 5 \% \mathrm{CO}_{2}$. After incubation for 11 to 14 days, the confluent cultures were shaken overnight at $260 \mathrm{rpm}$ at $37^{\circ}$ $\mathrm{C}$, and the adherent cells were trypsinized and re-seeded in the growth medium. More than $95 \%$ of the cells were astrocytes as confirmed by immunofluorescence staining for glial fibrillary acidic protein (GFAP).

All animal experiments were carried out in accordance with the National Institutes of Heath Guide for the Care and Use of Laboratory Animals. We made every effort to minimize the number of animals used and their suffering. The experimental protocols were approved by the Ethics Committee of Laboratory Animal Care and Welfare, School of Medicine, Zhejiang University.

\section{Cell migration (wound healing) assay}

Astrocytes were grown to confluence in 24-well plates and starved in serum-free DMEM for $24 \mathrm{~h}$. The monolayer cells were manually scratched with a $20-\mu l$ pipette tip to create an extended and definite scratch in the center of the dish with a bright and clear field. The detached cells were removed by washing with phosphate-buffered saline (PBS). DMEM containing 1\% FBS with or without TGF- $\beta 1$ (PeproTech Inc, Rocky Hill, NJ, USA) was added to each dish. In some experiments, $1 \mathrm{ng} / \mathrm{ml}$ TGF- $\beta 1$ was added to each dish for 30 minutes before treatment with $\mathrm{LTD}_{4}$ (Sigma-Aldrich Co., St Louis, MO, USA) or N-methyl $\mathrm{LTC}_{4}\left(\mathrm{NMLTC}_{4}\right.$, a metabolically stable $\mathrm{LTC}_{4}$ mimetic; Cayman Chemical 
Co., Ann Arbor, MI, USA). Cells were pretreated with the following inhibitor and antagonists: zileuton (0.01 to $5 \mu \mathrm{M}$, a 5-LOX inhibitor; Gaomeng Pharmaceutical Co., Beijing, China), montelukast (0.01 to $5 \mu \mathrm{M}$, a selective CysLT $_{1} \mathrm{R}$ antagonist; Merck \& Co., Inc., Whitehouse Station, NJ, USA), and Bay cysLT2 (0.01 to $5 \mu \mathrm{M}$, a selective $\mathrm{CysLT}_{2} \mathrm{R}$ antagonist; a kind gift from Dr. T. Jon Seiders of Amira Pharmaceuticals, Inc., San Diego, CA, USA) for 30 minutes, and then incubated with TGF- $\beta 1$ for $24 \mathrm{~h}$. Images of migratory cells from the scratch boundary were acquired at 0 and $24 \mathrm{~h}$ under a light microscope with a digital camera.

To continuously monitor migration time-course in live astrocytes, astrocytes were plated in $35-\mathrm{mm}$ dishes and grown to confluence, and then the cells were scratched and treated with $\mathrm{LTD}_{4}$ or/and TGF- $\beta 1$ as described above. The movements of live astrocytes was traced under an inverse videomicroscope (Olympus IX81, Olympus Corp., Tokyo, Japan), and the wound was photographed at $0,6,12,18$ and $24 \mathrm{~h}$.

The wounded areas were analyzed with ImageTool 2.0 software (University of Texas Health Science Center, San Antonio, TX, USA). The wound healing effect is determined as the initial scratch area $(0 \mathrm{~h})$ after wounding minus the scratch area after treatment for $24 \mathrm{~h}$, or 6,12 , 18 and $24 \mathrm{~h}$ (live astrocytes), and reported as percentages of control values. Moreover, some astrocyte samples seeded on coverslips were visualized by GFAP immunofluorescence staining $24 \mathrm{~h}$ after scratching as the typical images.

\section{Cell proliferation assay}

To measure astrocyte proliferation, carboxyfluorescein diacetate succinimidyl ester (CFSE) green fluorescent dye (Invitrogen Corp., Carlsbad, CA, USA) dilution assay was performed according to the manufacturer's instructions and the reported method [41-43]. Briefly, astrocytes were grown to confluence in six-well plates and starved in serum-free DMEM for $24 \mathrm{~h}$, then the cells were washed twice with PBS and incubated in $5 \mu \mathrm{M}$ CFSE in PBS for 15 minutes at $37^{\circ} \mathrm{C}$, and subsequently washed twice with PBS. Then DMEM containing $1 \%$ FBS with or without TGF- $\beta 1$ or $\mathrm{LTD}_{4}$ was added to each plate. In some experiments, $1 \mathrm{ng} / \mathrm{ml}$ TGF- $\beta 1$ was added to each plate for 30 minutes before treatment with $\mathrm{LTD}_{4}$. The cells were harvested at $24 \mathrm{~h}$, and subjected to fluorescence activated cell sorting using the FC500MCL flow cytometer (Beckman Coulter, Inc., Brea, CA, USA). Proliferation was measured by loss of CFSE dye.

\section{CysLT $_{1}$ receptor knockdown by small interfering RNA (siRNA)}

RNA duplexes of 21 nucleotides specific for rat $\mathrm{CysLT}_{1} \mathrm{R}$ sequences were chemically synthesized, together with a non-silencing negative control siRNA. The $\mathrm{CysLT}_{1} \mathrm{R}$ siRNA sense sequence was: 5'-CAG CCU UCC AAG
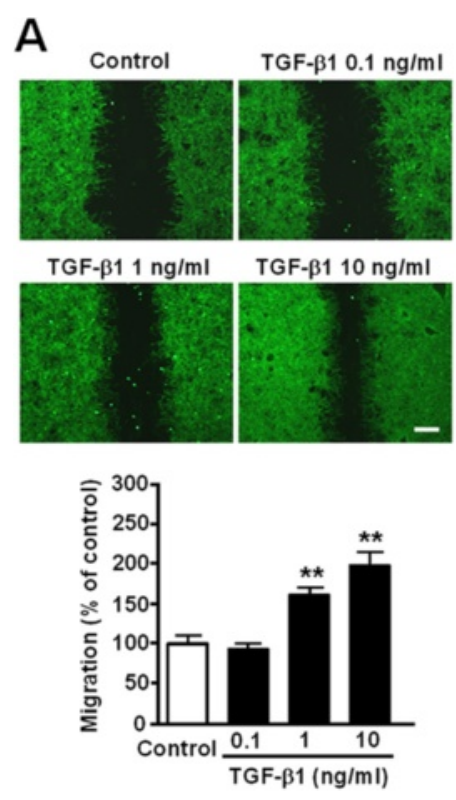
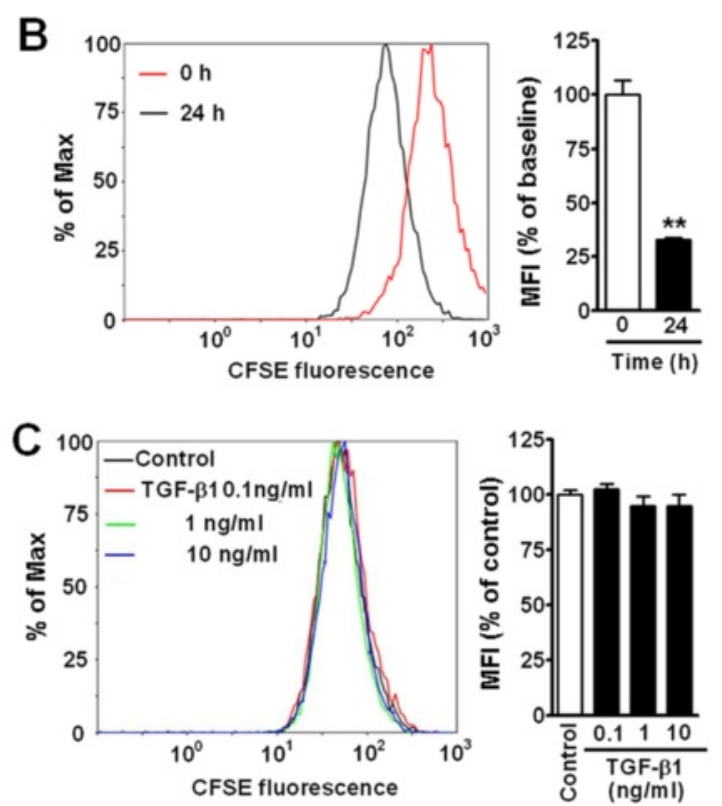

Figure 1 Effect of TGF- $\beta 1$ on astrocyte migration and proliferation. (A) Photomicrographs showing migration after treatment with TGF- $\beta 1$ $(0.1$ to $10 \mathrm{ng} / \mathrm{ml}$ ) for $24 \mathrm{~h}$. Scale bar, $400 \mu \mathrm{m}$. (B, C) Fluorescence intensity was determined by fluorescence activated cell sorting after CFSE labeling at 0 (baseline) and $24 \mathrm{~h}$. Mean fluorescence intensity (MFI) at $24 \mathrm{~h}$ reduced compared with baseline (B), but did not change $24 \mathrm{~h}$ after treatment with TGF- $\beta 1$ (0.1, 1 and $10 \mathrm{ng} / \mathrm{ml}$, C). Data are reported as mean \pm S.E.M.; $n=8$ (A), 3 (B) or 9 (C); **P $<0.01$ compared with control. 


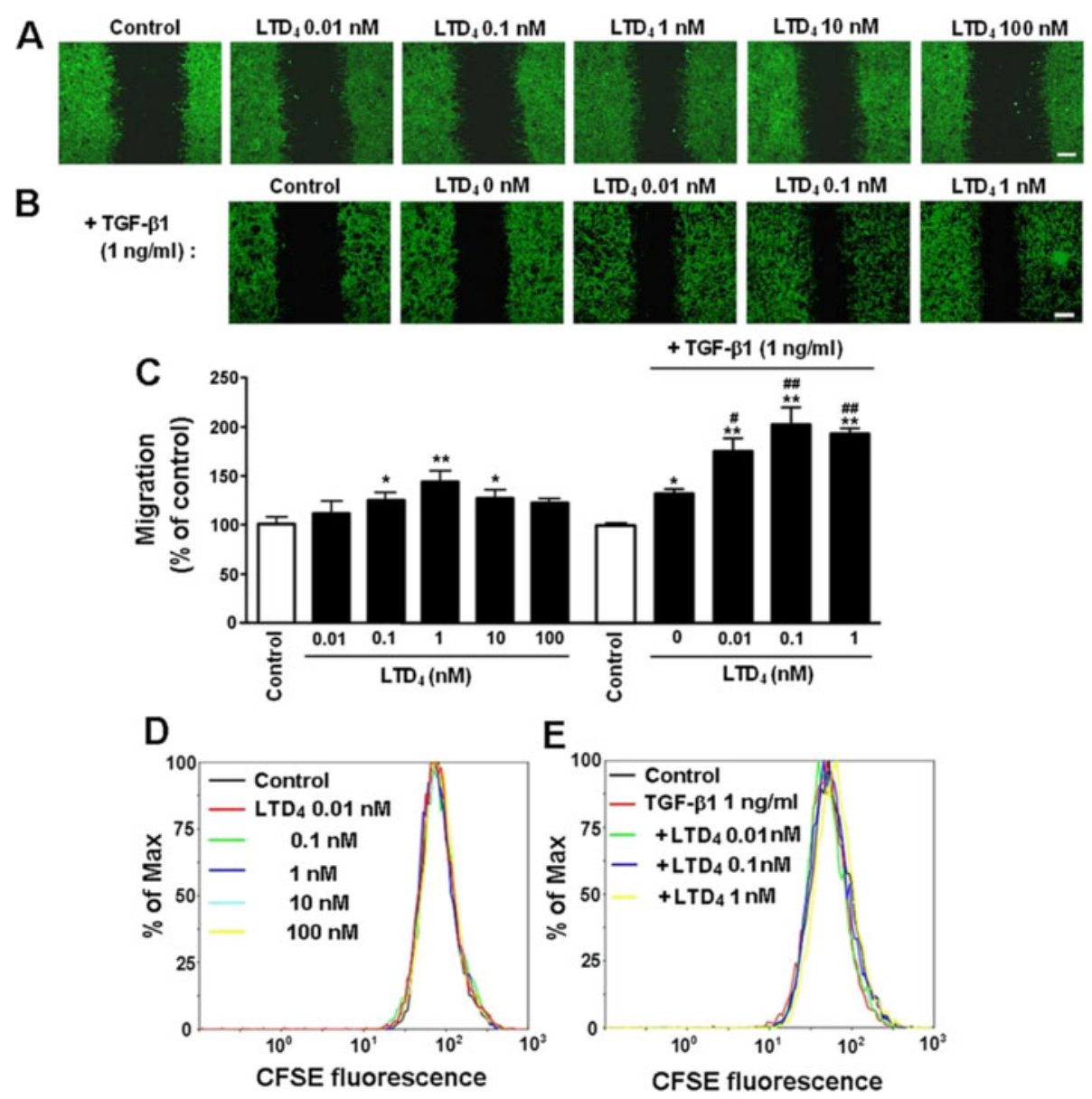

Figure 2 Effect of $\mathrm{LTD}_{4}$ on astrocyte migration and TGF- $\beta 1$-induced migration and proliferation. $(\mathrm{A}, \mathrm{B})$, Photomicrographs showing astrocyte migration $24 \mathrm{~h}$ after treatment with $\mathrm{LTD}_{4}(0.01 \mathrm{to} 100 \mathrm{nmol} / \mathrm{L})$ in the absence (A) or presence of TGF- $\beta 1(1 \mathrm{ng} / \mathrm{ml}, \mathrm{B})$. Scale bars, $400 \mu \mathrm{m}$. (C) Data are reported as mean \pm S.E.M.; $n=8$; ${ }^{*} P<0.05$ and ${ }^{* *} P<0.01$ compared with control, ${ }^{\#} P<0.05$ and ${ }^{\# \#} P<0.01$ compared with TGF- $\beta 1$ alone $\left(\mathrm{LTD}_{4}\right.$ 0). (D, E) MFI at $24 \mathrm{~h}$ was no significant change $24 \mathrm{~h}$ after treatment with $\mathrm{LTD}_{4}(0.01$ to $100 \mathrm{nM}, \mathrm{D})$ alone or combined with TGF- $\beta 11 \mathrm{ng} / \mathrm{ml}(\mathrm{E})(n=9$ for each group, $P>0.05)$.

UAU ACA UTT-3' and anti-sense: 5'-AUG UAU ACU UGG AAG GCU GTT-3'; the non-silencing control siRNA sense: 5'-UUC UCC GAA CGU GUC ACG UTT-3' and anti-sense: 5' -ACG UGA CAC GUU CGG AGA ATT-3' (GenePharma Co., Shanghai, China). Transfection of siRNA duplexes was performed according to the manufacturer's instructions. Briefly, astrocytes were seeded on the day before transfection using an appropriate medium with $10 \%$ FBS without antibiotics. They were transiently transfected with $\mathrm{CysLT}_{1} \mathrm{R}$ siRNA or negative control siRNA (100 nM) for $6 \mathrm{~h}$ using Lipofectamine $^{\text {rt }} 2000$ (Invitrogen, USA). After the transfected cells were incubated for $48 \mathrm{~h}$, they were treated with $\mathrm{LTD}_{4}$ or TGF- $\beta 1$ for cell migration assay.

\section{Reverse transcription-polymerase chain reaction (RT-PCR)} At the end of the experiments, total RNA was extracted from the cultured astrocytes using Trizol reagent
(Invitrogen, USA) according to the manufacturer's instructions. The cDNA synthesis and PCR reactions were performed as reported previously $[29,30]$. The PCR primers were: 5-LOX forward 5'-AAA GAA CTG GAA ACA GCT CAG AAA-3' and reverse 5'-AAC TGG TGT GTA CAG GGG TCA GTT-3'; CysLT $_{1}$ R, forward 5' - ATG TTC ACA AAG GCA AGT GG -3' and reverse $5^{\prime}$-TGC ATC CTA AGG ACA GAG TCA -3'; CysLT $_{2} \mathrm{R}$, forward $5^{\prime}$ - ACC CCT TCC AGA TGC TCC A $-3^{\prime}$ and reverse $5^{\prime}$ - CGT GCT TTG AAA TTC TCT CCA -3'; $\beta$-actin, forward 5'-AAC CCT AAG GCC AACCGT GAA-3' and reverse $5^{\prime}$-TCA TGA GGT AGT CTG TCA GGT C-3'; TGF- $\beta 1$, forward 5' - GAC CGC AAC AAC GCA ATC TA $-3^{\prime}$ and reverse 5'- AGG TGT TGA GCC CTT TCC AG -3 '.

For cDNA synthesis, $2 \mu \mathrm{g}$ total RNA was mixed with $1 \mathrm{mM}$ deoxynucleotide triphosphate, $0.2 \mu \mathrm{g}$ random primer, $20 \mathrm{U}$ RNasin and $200 \mathrm{U}$ M-MuLV reverse 


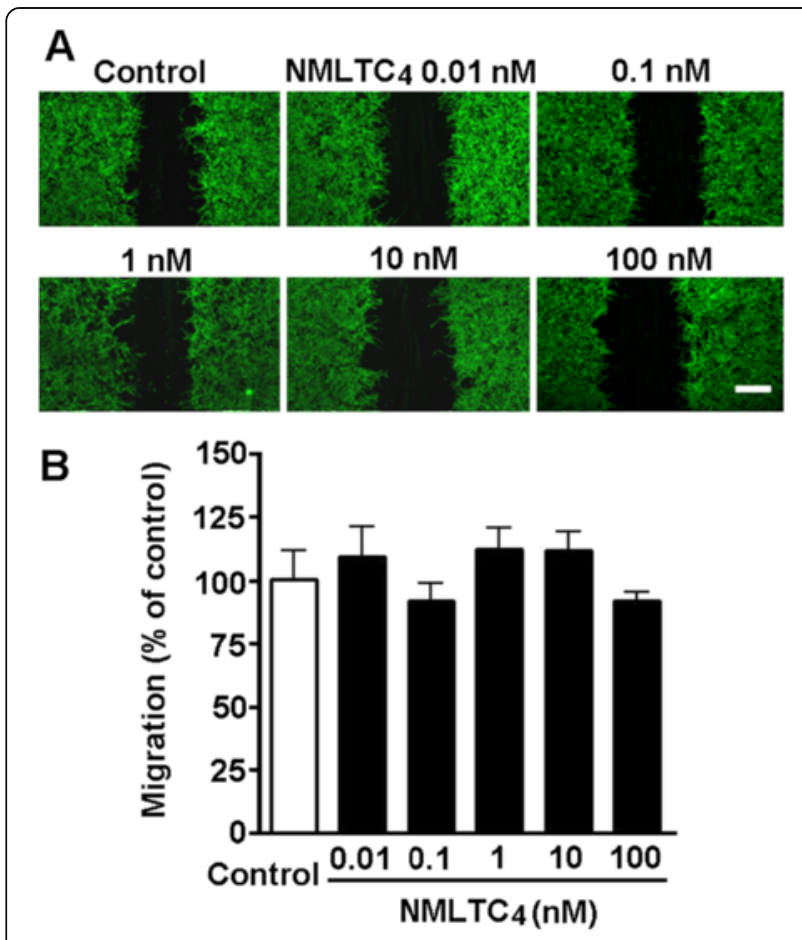

Figure 3 Effect of $\mathrm{NMLTC}_{4}$ on astrocyte migration. (A)

Photomicrographs showing astrocyte migration $24 \mathrm{~h}$ after treatment with $\mathrm{NMLTC}_{4}(0.01$ to $100 \mathrm{nmol} / \mathrm{L})$. (B) Data are reported as mean \pm S.E.M.; $n=8$. Scale bar, $400 \mu \mathrm{m}$.

transcriptase in $20 \mu \mathrm{l}$ reverse reaction buffer. The mixture was incubated at $42^{\circ} \mathrm{C}$ for 60 minutes, and then heated at $72^{\circ} \mathrm{C}$ for 10 minutes to inactivate the reverse transcriptase.

PCR was performed on an Eppendorf Master Cycler (Eppendorf Scientific, Inc., Westbury, NY, USA) as follows: $1 \mu \mathrm{l}$ cDNA mixture was reacted in $20 \mu$ l reaction buffer containing $1.5 \mathrm{mM} \mathrm{MgCl} 2,0.2 \mathrm{mM}$ deoxynucleotide triphosphate, $20 \mathrm{pM}$ primer and $1 \mathrm{U}$ Taq DNA polymerase. The reaction mixtures were initially heated at $94^{\circ} \mathrm{C}$ for 2 minutes, then at $94^{\circ} \mathrm{C}$ for $60 \mathrm{sec}, 56^{\circ} \mathrm{C}$ for $60 \mathrm{sec}$, and $72^{\circ} \mathrm{C}$ for $60 \mathrm{sec}$ for 35 cycles and finally stopped at $72^{\circ} \mathrm{C}$ for 10 minutes. With the exception of TGF- $\beta 1$, the reaction mixtures were initially heated at $94^{\circ} \mathrm{C}$ for 2 minutes, then at $94^{\circ} \mathrm{C}$ for $30 \mathrm{sec}, 54^{\circ} \mathrm{C}$ for $30 \mathrm{sec}$, and $72^{\circ} \mathrm{C}$ for $60 \mathrm{sec}$ for 28 cycles and finally stopped at $72^{\circ} \mathrm{C}$ for 10 minutes. PCR products of $20 \mu \mathrm{l}$ were separated by $2 \%$ agarose gel electrophoresis and visualized by ethidium bromide staining. The density of each band was measured by a UVP gel analysis system (Bio-Rad Laboratories, Hercules, CA, USA). The results are expressed as the ratios to $\beta$-actin.

\section{Western blotting analysis}

Astrocytes were washed twice with ice-cold PBS and then lysed for 30 minutes on ice in Cell and Tissue Protein
Extraction Solution (Kangcheng Biotechnology Inc., Shanghai, China). The homogenate was centrifuged at $12,000 \mathrm{~g}$ for 30 minutes at $4^{\circ} \mathrm{C}$, and the supernatant was used. The protein samples $(100 \mu \mathrm{g})$ were separated by $10 \%$ SDS-polyacrylamide gels and then transferred to nitrocellulose membranes (Invitrogen). The membranes were blocked by $10 \%$ fat-free milk, and sequentially incubated with the following antibodies: rabbit polyclonal antibody against CysLT $_{1} \mathrm{R}(1: 200)$ [44], CysLT $_{2} \mathrm{R}(1: 200)[26,45]$ or 5-LOX (1:300, (Chemicon International Inc. Temecula, CA, USA) and mouse monoclonal antibody against glyceraldehyde 3-phosphate dehydrogenase (GAPDH) (1:5,000, Kangcheng Biotechnology Inc., Shanghai, China) at $4^{\circ} \mathrm{C}$ overnight. After repeated wash, the membranes were incubated with anti-rabbit IRDye700DX ${ }^{\circledR}$-conjugated antibody or anti-mouse IRDye800DX ${ }^{\circledR}$-conjugated antibody (1:5,000, Rockland Immunochemicals, Inc., Gilbertsville, PA, USA). The immunoblot was analyzed by the Odyssey Fluorescence Scanner (LI-COR Bioscience, Inc., Lincoln, NE, USA). The protein bands were quantified using BIORAD Quantity One software (Bio-Rad, USA). The results are expressed as the ratios to GAPDH.

\section{Immunofluorescence staining}

Astrocytes seeded on coverslips were fixed in cold methanol for 5 minutes, and incubated in 10\% normal goat serum for $2 \mathrm{~h}$ to block non-specific binding of IgG. Then the cells were reacted with a mouse monoclonal antibody against GFAP (1:500, Millipore Corp., Bedford, MA, USA) and a rabbit polyclonal antibody against CysLT $_{1} \mathrm{R}\left(1: 200\right.$, Chemicon, USA) at $4^{\circ} \mathrm{C}$ overnight. After washing in PBS, astrocytes were incubated with FITCconjugated goat anti-mouse or Cy3-conjugated goat anti-rabbit antibody (1:200, Millipore, USA) for $2 \mathrm{~h}$ at room temperature. Finally, the stained cells were observed under a fluorescence microscope (Olympus BX51, Olympus Corp., Tokyo, Japan). Control coverslips were treated with normal goat serum instead of the primary antibody, and did not show positive immunostaining (data not shown).

\section{5-LOX immunocytochemistry}

Astrocytes cultured on coverslips were fixed in cold methanol $\left(-20^{\circ} \mathrm{C}\right)$ for 5 minutes and incubated for 30 minutes in PBS containing $3 \% \mathrm{H}_{2} \mathrm{O}_{2}$ to eliminate endogenous peroxidase activity. Then, cells were incubated for $2 \mathrm{~h}$ in PBS containing 10\% normal goat serum and incubated at $4^{\circ} \mathrm{C}$ overnight with rabbit polyclonal antibody against 5 -LOX (1:200, Chemicon, USA) as the primary antibody. After three washes with PBS, cells were incubated for $2 \mathrm{~h}$ with biotin-conjugated goat anti-rabbit IgG antiserum (1:200) as a second antibody, followed by incubation with avidin-biotin-HRP complex. Finally, the cells were visualized with $0.01 \% 3,3$ '-diaminobenzidine 

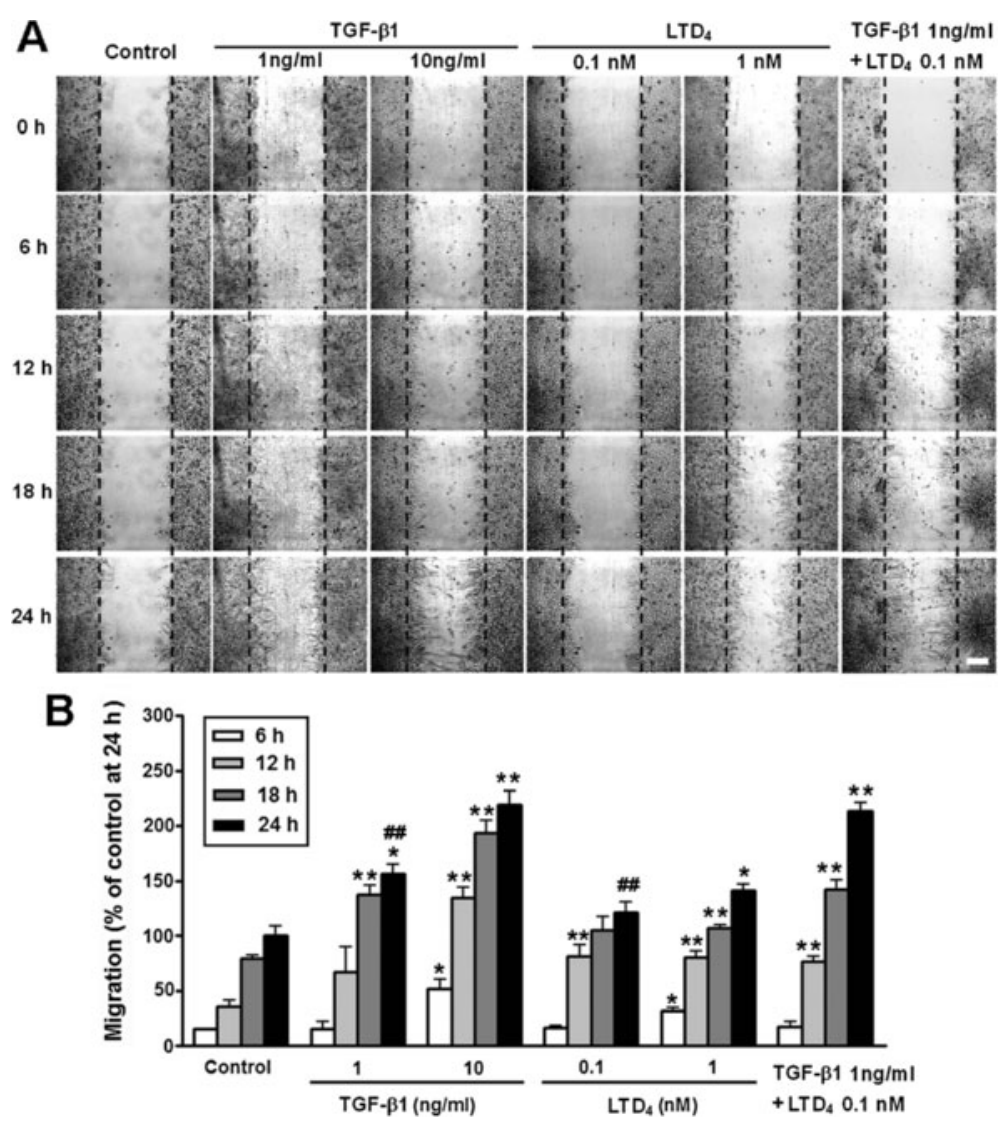

Figure 4 Time-dependent migration of live astrocytes after exposure to TGF- $\beta 1$ and LTD 4 . Live astrocytes were continuously monitored under a videomicroscope after exposure to TGF- $\beta 1$ or/and $\mathrm{LTD}_{4}$. (A) Representative images showing astrocyte migration traced by videomicroscopy at 6, 12, 18 and $24 \mathrm{~h}$ after scratching. Scale bar, $200 \mu \mathrm{m}$. (B) TGF- $\beta 1$ and LTD 4 concentration- and time-dependently accelerated migration. When TGF- $\beta 1(1 \mathrm{ng} / \mathrm{ml})$ combined with $\mathrm{LTD}_{4}(0.1 \mathrm{nM})$, the effect at $24 \mathrm{~h}$ was more potent than that of TGF- $\beta 1$ or LTD 4 alone. Data are reported as mean \pm S.E.M.; $n=3 ;{ }^{*} P<0.05$ and ${ }^{*} P<0.01$ compared with corresponding time-points of the control; $\# P<0.01$ compared with TGF- $\beta 1+L^{2 T D}$ at $24 \mathrm{~h}$.

and $0.005 \% \mathrm{H}_{2} \mathrm{O}_{2}$ in $50 \mathrm{mM}$ Tris- $\mathrm{HCl}$, $\mathrm{pH}$ 7.6. Control coverslips were treated with normal goat serum instead of the primary antibody and they did not show positive immunostaining (data not shown). Then, the cells were examined under the Olympus microscope.

\section{Measurement of extracellular cysteinyl leukotrienes and TGF- $\beta 1$}

According to the reported method [29,30], astrocytes were seeded into six-well culture plates at $5 \times 10^{5}$ cells/ well in $2 \mathrm{ml}$ standard culture medium for $24 \mathrm{~h}$. After culture in DMEM without serum for another $24 \mathrm{~h}$, astrocytes were cultured in DMEM with $1 \%$ FBS and stimulated with TGF- $\beta 1(10 \mathrm{ng} / \mathrm{mL})$, various concentrations of $\mathrm{LTD}_{4}$ or $\mathrm{NMLTC}_{4}$, or vehicle for the designated times. Then, cell-free supernatants were stored at $-80^{\circ} \mathrm{C}$. The CysLTs $\left(\mathrm{LTC}_{4}, \mathrm{LTD}_{4}\right.$ and $\left.\mathrm{LTE}_{4}\right)$ in astrocyte supernatants were assayed using a commercial CysLT ELISA kit (Cayman Chemical Co., Ann Arbor, MI, USA) according to the manufacturer's instructions and calculated as $\mathrm{pg} / \mathrm{mg}$ protein. The TGF- $\beta 1$ in the supernatants was assayed using a commercial TGF- $\beta 1$ ELISA kit (Wuhan Boster Biological Technology Co., Ltd., Wuhan, China) according to the manufacturer's instructions, and calculated as $\mathrm{pg} / \mathrm{ml}$.

\section{Statistical analysis}

Data are reported as mean \pm S.E.M. Student's $t$-test and one-way analysis of variance were used to determine the statistical significance of differences between groups. A value of $P<0.05$ was considered statistically significant.

\section{Results}

TGF- $\beta 1$ - and $\mathrm{LTD}_{4}$-induced astrocyte migration

First, we confirmed the effect of TGF- $\beta 1$ on astrocyte migration. TGF- $\beta 1$ ( 1 and $10 \mathrm{ng} / \mathrm{ml}$ for $24 \mathrm{~h}$ ) significantly accelerated the migration of astrocytes from the wound edge into the central area in a concentration-dependent manner (Figure 1A). To distinguish the effects on migration and proliferation, we determined whether TGF- $\beta 1$ 


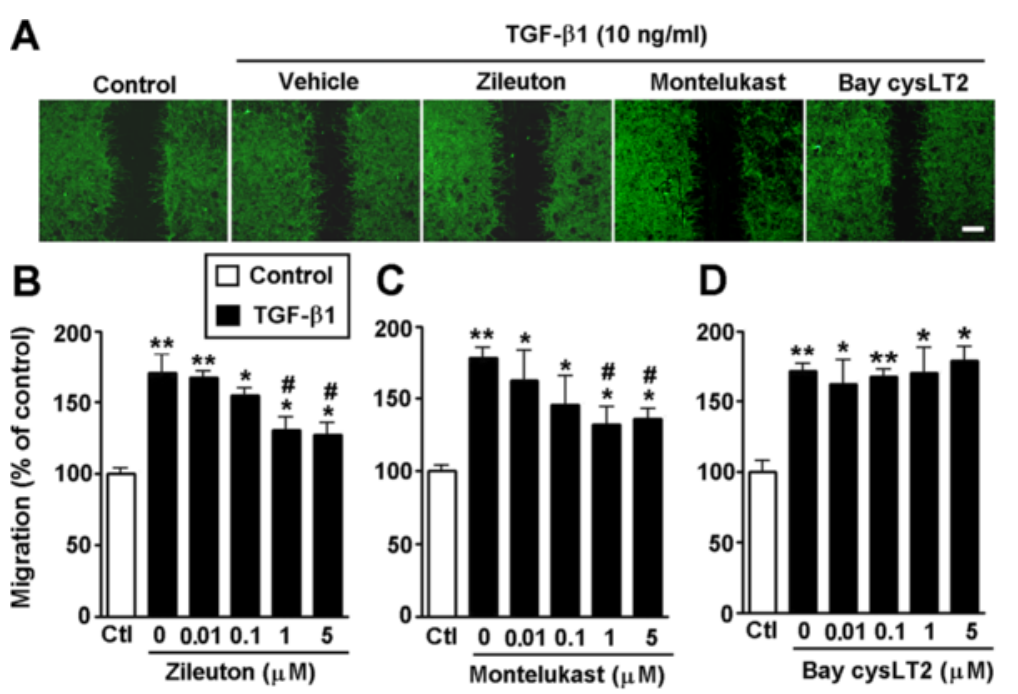

Figure 5 Effects of a 5-LOX inhibitor and CysLT receptor antagonists on TGF- $\beta$ 1-induced migration in astrocytes. (A) Photomicrographs showing TGF- $\beta 1$ (10 ng/ml)-induced astrocyte migration $24 \mathrm{~h}$ after treatment with the 5-LOX inhibitor zileuton, the CysLT,R antagonist montelukast and the CysLT 2 antagonist Bay cysLT2 $(1 \mu \mathrm{M})$. Scale bar, $400 \mu \mathrm{m}$. (B-D) TGF- $\beta 1$-induced migration inhibited by 0.01 to $5 \mu \mathrm{M}$ zileuton (B) and montelukast $(\mathbf{C})$, but not Bay cysLT2 (D). Data are reported as mean \pm S.E.M.; $n=8 ;{ }^{*} P<0.05$ and ${ }^{* *} P<0.01$ compared with control; $\# P<0.05$ compared with TGF- $\beta 1$ alone.

affects astrocyte proliferation. The results of CFSE fluorescence intensity showed that astrocyte proliferation did not differ from control level $24 \mathrm{~h}$ after exposure to TGF- $\beta 1$ $(0.1,1$ and $10 \mathrm{ng} / \mathrm{ml}$ ) (Figure $1 \mathrm{C}$ ) although the assay confirmed astrocyte proliferation at $24 \mathrm{~h}$ compared with $0 \mathrm{~h}$ (baseline) (Figure 1B).

Next, we determined whether the non-selective agonist $\mathrm{LTD}_{4}$ and the $\mathrm{CysLT}_{2} \mathrm{R}$ agonist $\mathrm{NMLTC}_{4}$ [46] induce astrocyte migration, and $\mathrm{LTD}_{4}$ potentiates the TGF- $\beta 1$ effect. The results showed that $\mathrm{LTD}_{4}$ significantly stimulated the migration of astrocytes at 0.1 to $10 \mathrm{nM}$ but not at 0.01 and $100 \mathrm{nM}$; the maximum migration $(141.7 \pm 5.0 \%)$ was induced by $1 \mathrm{nM} \mathrm{LTD}_{4}$ (Figure 2A, C). $\mathrm{LTD}_{4}(0.01$ to $1 \mathrm{nM})$ also potentiated the effect of the lower concentration of TGF- $\beta 1(1 \mathrm{ng} / \mathrm{ml})$; the migration rates after treatment with $1 \mathrm{ng} / \mathrm{ml}$ TGF- $\beta 1$ were increased from $110.3 \pm 5.4 \%$ to $175.3 \pm 4.8 \%$ with 0.01 $\mathrm{nM}$, from $123.5 \pm 4.0 \%$ to $203.5 \pm 5.3 \%$ with $0.1 \mathrm{nM}$, and from $141.7 \pm 5.0 \%$ to $193.8 \pm 2.9 \%$ with $1 \mathrm{nM} \mathrm{L_{D }}$ (Figure 2B, C). $\mathrm{LTD}_{4}(0.01$ to $100 \mathrm{nM}$ ) alone (Figure 2D) or combined with TGF- $\beta 11 \mathrm{ng} / \mathrm{ml}$ (Figure $2 \mathrm{E}$ ) did not affect astrocyte proliferation at $24 \mathrm{~h}$. However, $\mathrm{NMLTC}_{4}$ (0.01 to $100 \mathrm{nM}$ for $24 \mathrm{~h}$ ) did not have any significant effect on astrocyte migration (Figure 3). In addition, to confirm the migration and determine its temporal property, we continuously monitored migration of live astrocytes during $24 \mathrm{~h}$ after exposure to $\mathrm{LTD}_{4}$ or/and TGF- $\beta 1$. We found that TGF- $\beta 1$ ( 1 and $10 \mathrm{ng} / \mathrm{ml}$ ) and $\mathrm{LTD}_{4}(1 \mathrm{nM})$ gradually accelerated migration during $24 \mathrm{~h}$ in a concentration-dependent manner. When TGF- $\beta 1$ (1 ng/ml) combined with $\mathrm{LTD}_{4}(0.1 \mathrm{nM})$, the effect at
$24 \mathrm{~h}$ was more potent than that of TGF- $\beta 1$ or $\mathrm{LTD}_{4}$ alone (Figure 4).

To confirm the roles of endogenous CysLTs and CysLT $_{1} \mathrm{R}$ in TGF- $\beta 1$-induced migration, we examined the effects of the 5 -LOX inhibitor zileuton, the CysLT $_{1} R$ antagonist montelukast, and the $\operatorname{CysLT}_{2} \mathrm{R}$ antagonist Bay cysLT2 as well as CysLT $_{1} \mathrm{R}$ siRNA. We found that the effect of $10 \mathrm{ng} / \mathrm{ml}$ TGF- $\beta 1$ was attenuated by zileuton (1 and $5 \mu \mathrm{M}$, Figure $5 \mathrm{~A}, \mathrm{~B}$ ) and montelukast ( 1 and $5 \mu \mathrm{M}$, Figure $5 \mathrm{~A}, \mathrm{C})$, but not by Bay cysLT2 $(0.01$ to $5 \mu \mathrm{M}$, Figure 5A, D). These results indicated that endogenously released CysLTs might activate $\mathrm{CysLT}_{1} \mathrm{R}$, but not CysLT $_{2} R$, to induce astrocyte migration and potentiate TGF- $\beta 1$-induced migration. The involvement of CysLT $_{1} \mathrm{R}$ was further confirmed by RNA silencing by transient transfection of $\mathrm{CysLT}_{1} \mathrm{R}$ siRNA into astrocytes. The siRNA (100 nM) significantly reduced the expression of CysLT $_{1} R$ mRNA (Figure 6A) and protein (Figure 6B, C), but the non-silencing negative control siRNA had no effect. CysLT ${ }_{1} \mathrm{R}$ siRNA significantly attenuated the effects of $\mathrm{LTD}_{4}(1$ and $10 \mathrm{nM})$ and TGF- $\beta 1$ ( 1 and $10 \mathrm{ng} / \mathrm{ml}$ ) on astrocyte migration (Figure 6D, E). These results suggest that $\mathrm{CysLT}_{1} \mathrm{R}$ may be associated with $\mathrm{LTD}_{4}$ - and TGF- $\beta 1$-induced astrocyte migration.

\section{TGF- $\beta$ 1-Induced Activation of 5-LOX in astrocytes}

To investigate the role of endogenous CysLTs, the 5LOX metabolites, in TGF- $\beta 1$-induced astrocyte migration, we determined 5-LOX expression in astrocytes. We found that TGF- $\beta 110 \mathrm{ng} / \mathrm{ml}$ significantly increased 5-LOX mRNA (Figure 7A) and protein expression 

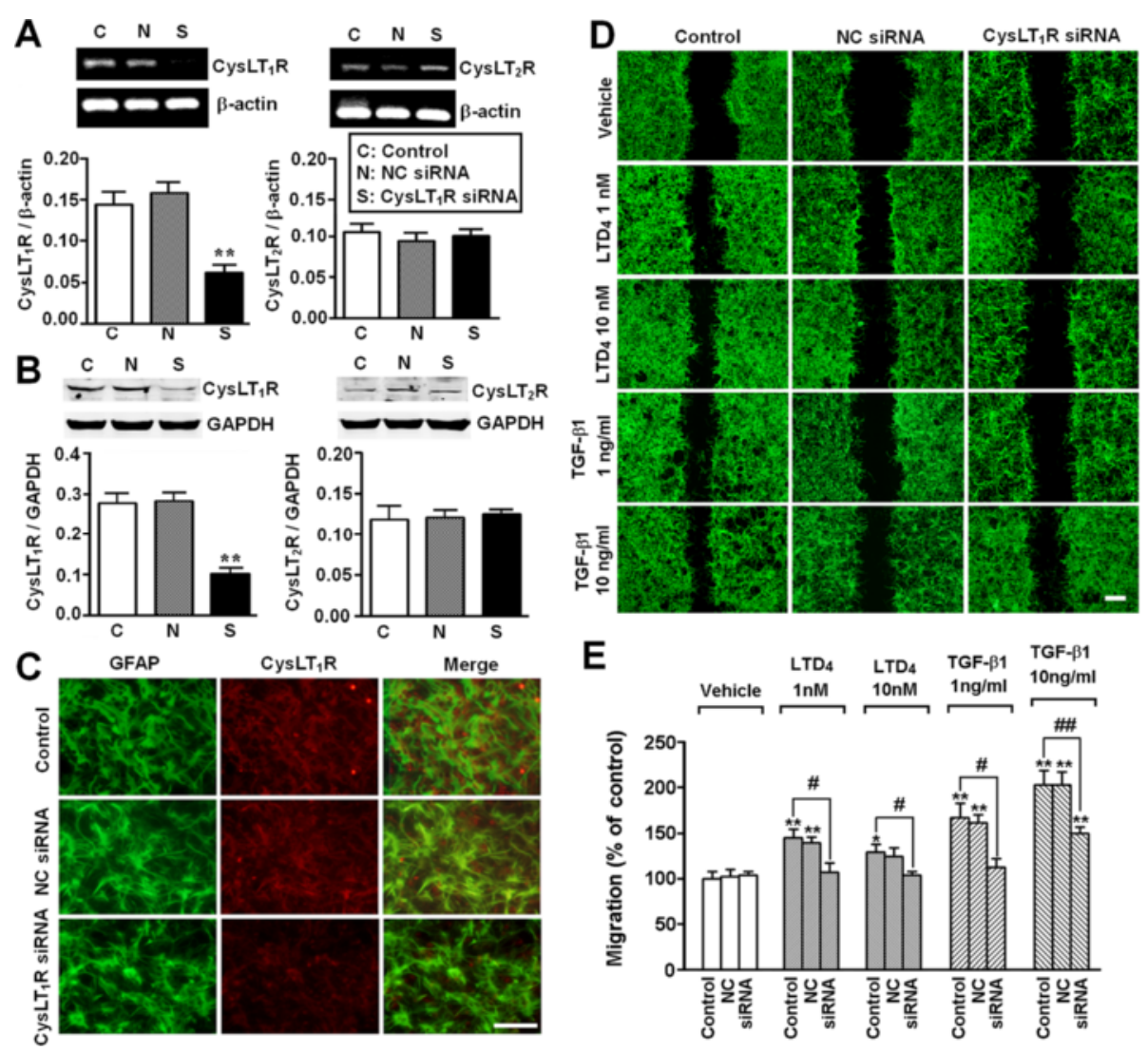

Figure 6 Effect of CysLT 1 R siRNA on LTD $_{4}$ - and TGF- $\beta$ 1-induced migration in astrocytes. (A, B) RT-PCR and Western blotting results showing inhibition of CysLT $R$, but not Cys $L T_{2} R$, mRNA (A) and protein expression (B) by Cys $L T_{1} R$ siRNA but not by negative control (NC) siRNA. (C) Double immunofluorescence staining showing inhibition of CysL $T_{1} R$ protein expression by Cys $L T_{1} R$ siRNA in GFAP-positive astrocytes. (D) Photomicrographs showing that the astrocyte migration induced by $\mathrm{LTD}_{4}(1$ and $10 \mathrm{nM})$ and TGF- $\beta 1$ ( 1 and $10 \mathrm{ng} / \mathrm{ml}$ ) was inhibited by CysLT $R$ siRNA (siRNA) but not by NC siRNA. (E) CysLT R siRNA inhibited migration induced by $L_{1} D_{4}$ and TGF- $\beta 1$. Data are reported as mean \pm S.E.M.; $n=4$ (A and B) or 8 (E); ${ }^{*} P<0.05$ and ${ }^{*} P<0.01$ compared with control; ${ }^{*} P<0.05$ and ${ }^{\# \#} P<0.01$ compared with $\mathrm{LTD}_{4}$ or TGF- $\beta 1$ alone. Scale bar, $200 \mu \mathrm{m}(\mathrm{C})$ or $400 \mu \mathrm{m}(\mathrm{D})$.

(Figure 7B) $24 \mathrm{~h}$ after exposure. Immunocytochemical results showed that 5 -LOX was translocated from the cytosol to the nuclear envelope 6 and $12 \mathrm{~h}$ after exposure to $10 \mathrm{ng} / \mathrm{ml}$ TGF- $\beta 1$, and then recovered at $24 \mathrm{~h}$ (Figure 7C). We further determined the changes in enzymatic activity of 5-LOX by measuring its metabolites, CysLTs, in the culture medium. The levels of CysLTs increased from $1.5 \mathrm{~h}$, peaked at $12 \mathrm{~h}$, and were sustained over $24 \mathrm{~h}$ after exposure to $10 \mathrm{ng} / \mathrm{ml} \mathrm{TGF- \beta 1}$ (Figure 7D). These findings revealed the involvement of 5 -LOX and its metabolite CysLTs in the responses to TGF- $\beta 1$.

\section{TGF- $\beta 1$-regulated expression of CysLT receptor in astrocytes}

Finally, we determined whether TGF- $\beta 1$ regulates the expression of $\mathrm{CysLT}_{1} \mathrm{R}$ and $\mathrm{CysLT}_{2} \mathrm{R}$ mRNA and protein in astrocytes, and whether $\mathrm{LTD}_{4}$ regulates TGF- $\beta 1$ expression and release. RT-PCR and Western blot showed weak expression of $\mathrm{CysLT}_{1} \mathrm{R}$ and $\mathrm{CysLT}_{2} \mathrm{R}$ in control astrocytes. Exposure to $10 \mathrm{ng} / \mathrm{ml}$ TGF- $\beta 1$ for $24 \mathrm{~h}$ induced about three-fold increase in the mRNA (Figure 8A) and protein expression (Figure 8B) of CysLT $_{1} \mathrm{R}$, but did not significantly change the expression of $\mathrm{CysLT}_{2} \mathrm{R}$. Immunofluorescence staining confirmed the enhancement of $\mathrm{CysLT}_{1} \mathrm{R}$ by TGF- $\beta 1$ (Figure $8 \mathrm{C}$ ). On the other hand, treatment with various concentrations of $\mathrm{LTD}_{4}$ or $\mathrm{NMLTC}_{4}$ for $24 \mathrm{~h}$ did not affect the TGF- $\beta 1$ mRNA expression in astrocytes (Figure 9A) and its content in the culture medium (Figure 9B). Thus, TGF- $\beta 1$ might up-regulate $\operatorname{CysLT}_{1} \mathrm{R}$ but is not regulated by $\mathrm{LTD}_{4}$.

\section{Discussion}

In the present study, we revealed that TGF- $\beta 1$-induced astrocyte migration is, at least in part, mediated by enhanced endogenous CysLTs through activation of CysLT $_{1} R$. The evidence is that TGF- $\beta 1$-induced astrocyte migration was potentiated by $\mathrm{LTD}_{4}$ but attenuated by a 5-LOX inhibitor and a $\operatorname{CysLT}_{1} \mathrm{R}$ antagonist, and TGF- $\beta 1$ activated 5-LOX and increased CysLT $_{1} R$ 


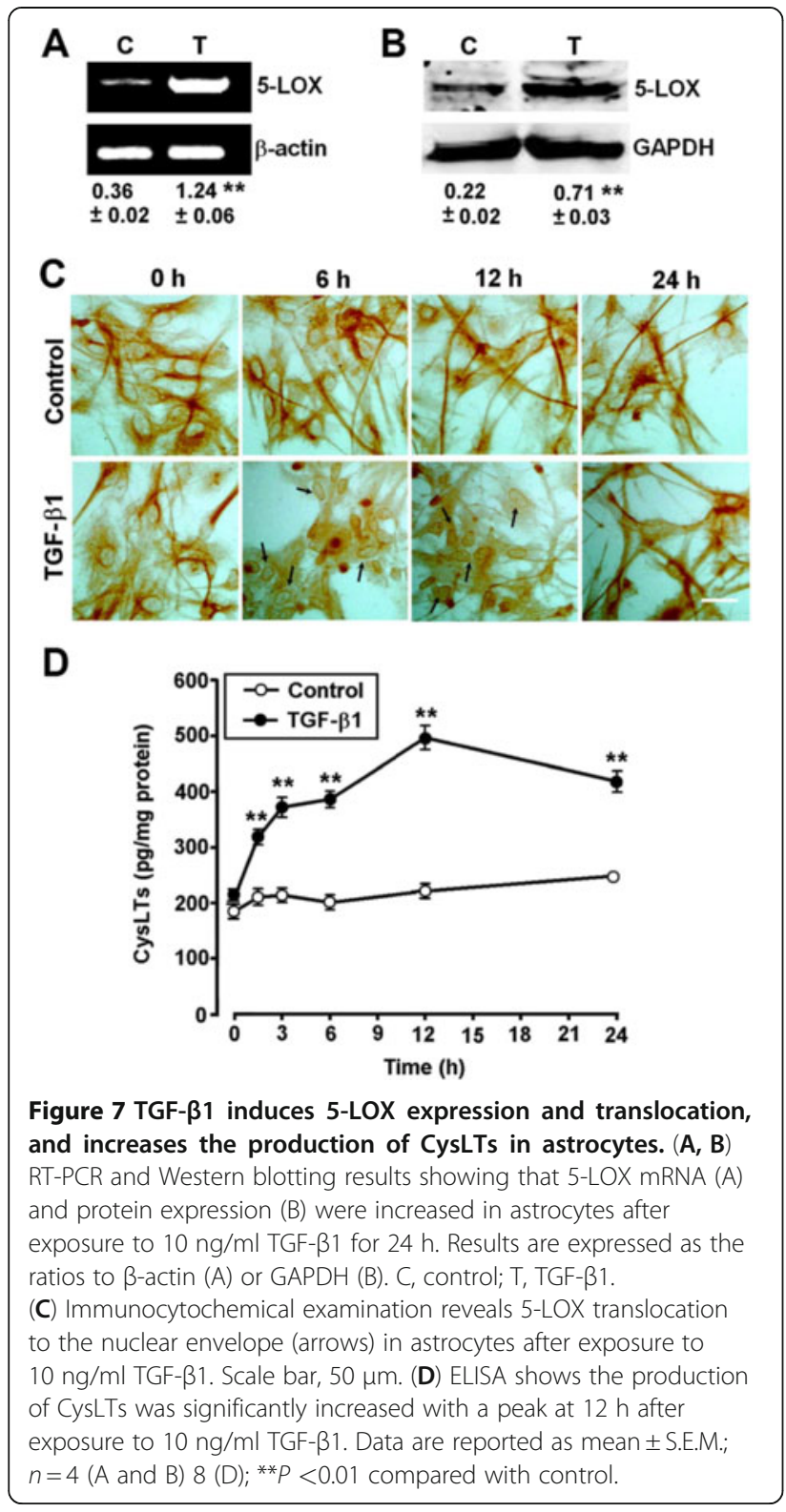

expression. Our observations have confirmed the TGF$\beta 1$-induced migration of rat astrocytes as reported [6], and indicated another mechanism underlying TGF- $\beta 1$ induced astrocyte migration in addition to the pathways through activation of the Smad family $[47,48]$ or the ROS-dependent ERK/JNK-NF- $k B$ pathway [6]. In addition, we found that both TGF- $\beta 1$ and $\mathrm{LTD}_{4}$ did not alter astrocyte proliferation during $24 \mathrm{~h}$. It has been reported that TGF- $\beta 1$ inhibits astrocyte proliferation $[47,49,50]$ and $\mathrm{LTD}_{4}$ induces the proliferation via activating CysLT $_{1} \mathrm{R}$ [30]. This difference between these reported results and ours may result from different assessment timing [30] and methods $[47,49,50]$. However, in our experimental conditions, TGF- $\beta 1$ and $\mathrm{LTD}_{4}$ regulate astrocyte migration rather than proliferation.

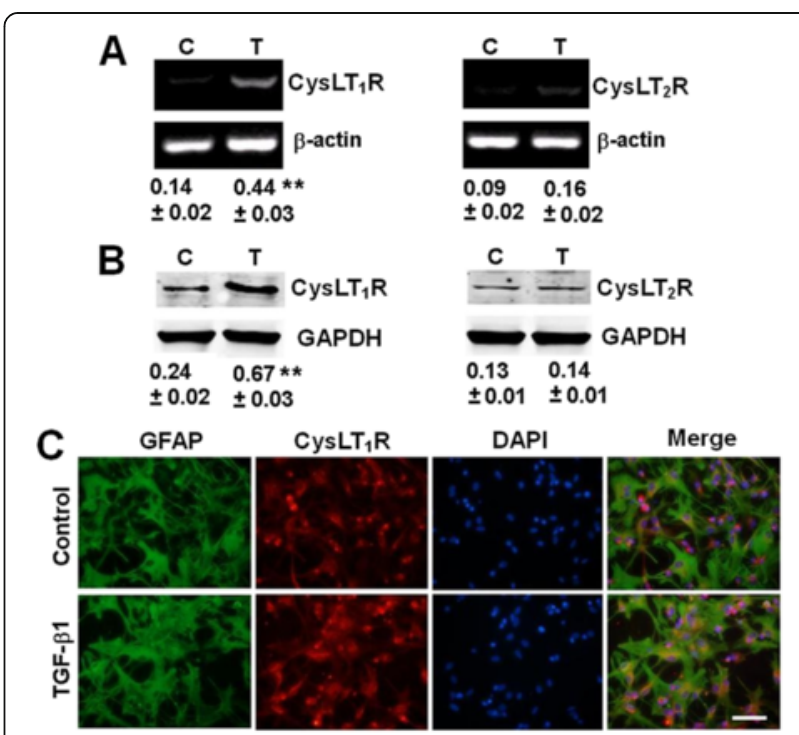

Figure 8 Effect of TGF- $\beta 1$ on expression of CysLT receptors in astrocytes. (A, B) RT-PCR and Western blotting results showing that the mRNA (A) and protein expression (B) of CysLT, R, but not Cys $L T_{2} R$, in astrocytes increased after exposure to $10 \mathrm{ng} / \mathrm{ml}$ TGF- $\beta 1$ for 24 h. Data are reported as mean \pm S.E.M.; $n=4 ; * * P<0.01$ compared with control. Results are expressed as the ratios to $\beta$-actin (A) or GAPDH (B). C, control; T, TGF- $\beta 1$. (C) Double immunofluorescence staining showing that TGF- $\beta 1$ increased the expression of CysLT $R$ in GFAP-positive astrocytes. Scale bar, $100 \mu \mathrm{m}$.

TGF- $\beta 1$-induced astrocyte migration might be mediated by the CysLT signal pathway in at least two ways, that is, TGF- $\beta 1$ potentiates the activity of both 5 -LOX and CysLT $_{1} R$. On one hand, TGF- $\beta 1$ increased 5 -LOX expression and induced its translocation to the nuclear envelope (Figure 7C), a key step for 5-LOX activation [5153] and, thereby, increased the production of endogenous CysLTs (Figure 7D). Consistent with this, it has been reported that TGF- $\beta 1$ induces 5 -LOX expression in myeloid cell lines [54-58]. The notion is also supported by the finding that the TGF- $\beta 1$ effect was inhibited by the 5LOX inhibitor zileuton (Figure 5A). On the other hand, TGF- $\beta 1$ potentiates the expression of CysLT $_{1} R$, enhancing the activity of endogenously-produced or exogenous CysLTs as previously reported $[37,39]$. Therefore, one of the mechanisms underlying TGF- $\beta 1$-induced astrocyte migration may be activation of endogenous 5-LOX $/$ CysLT $_{1} \mathrm{R}$ signals.

Here, we demonstrated that the receptor subtype that mediated the TGF- $\beta 1$ effect was $C_{y s L T} R$. The evidence was from the different effects of agonists and antagonists, and the effect of RNA interference. The nonselective agonist $\mathrm{LTD}_{4}$ induced a moderate migration of astrocytes at lower concentrations $(0.1$ to $10 \mathrm{nM})$, but not at the higher concentrations $100 \mathrm{nM}$ (Figure 2A, C) and 1,000 nM (data not shown). This concentrationresponse relationship indicated that $\mathrm{CysLT}_{1} \mathrm{R}$ might 


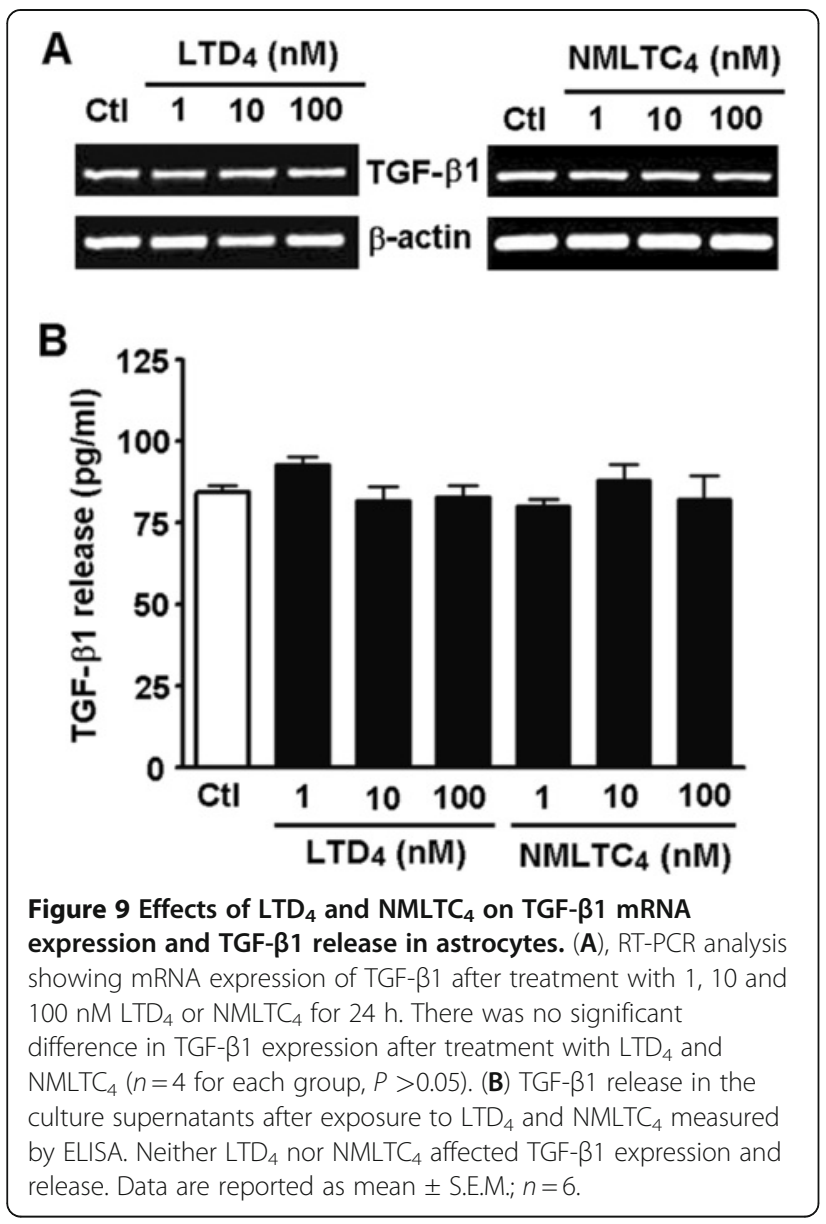

mediate the effect of $\mathrm{LTD}_{4}$, because CysLT ${ }_{1} \mathrm{R}$ is activated at 1 to $10 \mathrm{nM}$ while $\operatorname{CysLT}_{2} \mathrm{R}$ is activated at 100 to 1,000 $\mathrm{nM}$ in astrocytes [30]. This is also supported by the finding that the selective $\mathrm{CysLT}_{2} \mathrm{R}$ agonist $\mathrm{NMLTC}_{4}[46]$ had no effect on astrocyte migration (Figure 3). With regard

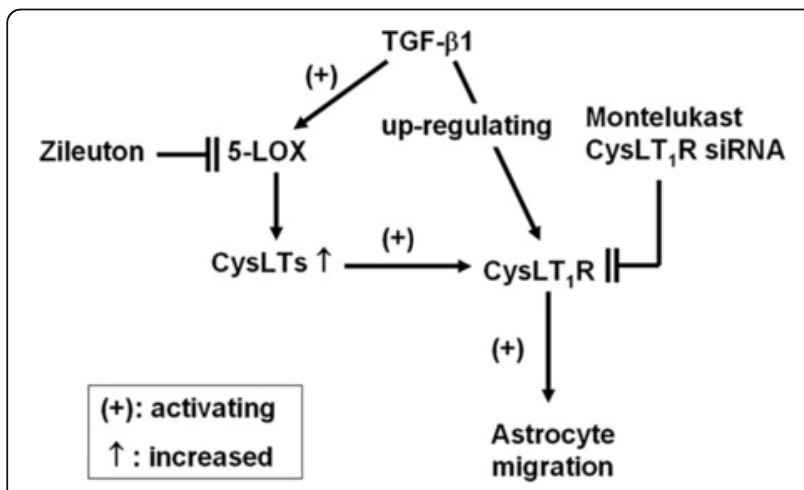

Figure 10 Diagram showing the roles of TGF- $\beta 1$ and 5-LOX/

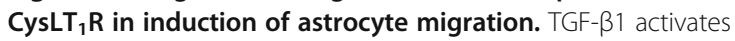
5-LOX to produce CysLTs; the latter activates CysLT,R. Meanwhile, it also up-regulates $C y s L T_{1} R$ expression, which enhances the activity of Cys $L T, R$. The activated CysLT $R$ mediates TGF- $\beta 1$-induced astrocyte migration. to receptor antagonism, the effect of TGF- $\beta 1$ was attenuated by the $\mathrm{CysLT}_{1} \mathrm{R}$ antagonist montelukast but not by the CysLT $_{2} \mathrm{R}$ antagonist Bay cysLT2. Bay cysLT2 is at least 100- to 500 -fold more selective for $\mathrm{CysLT}_{2} \mathrm{R}$ versus CysLT ${ }_{1} \mathrm{R}$; its $\mathrm{pA}_{2}$ value indicates that at least $5 \mu \mathrm{M}$ would act on the CysLT 1 R $[59,60]$. Thus, lacking the effect of $5 \mu \mathrm{M}$ Bay ctsLT2 in our study may be due to cell specificity and response difference. On the other hand, interference with $\mathrm{CysLT}_{1} \mathrm{R}$ siRNA inhibited both TGF- $\beta 1$ - and LTD $_{4}$-induced astrocyte migration by down-regulating the expression of this receptor (Figure 6). These findings are consistent with reports that CysLT $_{1} R$ mediates the migration of other types of cells [31-36]. Therefore, CysLT $_{1} R$ is an important regulator of astrocyte migration in addition to its regulation of astrocyte proliferation $[29,30]$.

The interaction between TGF- $\beta 1$ and CysLTs was also investigated by determining the action of $\mathrm{LTD}_{4}$ or $\mathrm{NMLTC}_{4}$ on TGF- $\beta 1$ expression and release. Unlike the action of TGF- $\beta 1$ on the production of CysLTs and $\mathrm{LTD}_{4}$ effects, $\mathrm{LTD}_{4}$ or $\mathrm{NMLTC}_{4}$ affected neither TGF- $\beta 1$ expression nor its release in astrocytes (Figure 9). This may depend on specific cell types because $\mathrm{LTD}_{4}$ induces TGF- $\beta 1$ mRNA expression in human bronchial epithelial cells $[61,62]$ and in fibroblasts from asthmatics [63], and $\mathrm{LTC}_{4}$ induces TGF- $\beta 1$ production in airway epithelium [62] in a CysLT ${ }_{1} R$-dependent manner. Anyway, the effect of $\mathrm{LTD}_{4}$ on TGF- $\beta 1$ in astrocytes remains to be further investigated, especially in animal models of chronic brain injury. Since both levels of TGF- $\beta 1$ and CysLTs are increased after brain injury $[24,64,65]$ and involved in glial scar formation $[25,65,66]$; which of them is determinant in glial scar formation should be clarified for their therapeutic implications. Herein, our results suggest that activation of the endogenous 5 -LOX/CysLT ${ }_{1} \mathrm{R}$ signals might be an intermediate event in TGF- $\beta 1$ regulated astrocyte migration, but not the initial event. Since TGF- $\beta 1$ signaling is mainly modulated by Smaddependent [67-75] and Smad-independent pathways [6,76-81], whether the regulation mode is mediated by the Smad or other pathways requires investigation.

Astrocyte migration is a critical step in the formation of a densely-packed glial scar [1,2], and TGF- $\beta 1$ is closely associated with glial scar formation [64,66,82-84]. Thus, CysLT receptor antagonists or 5-LOX inhibitors may be beneficial in the prevention and attenuation of glial scar formation after brain injury. Actually, we have reported that the $\mathrm{CysLT}_{1} \mathrm{R}$ antagonist pranlukast attenuates glial scar formation in the chronic phase of focal cerebral ischemia in mice [28] and rats [25], and the 5LOX inhibitor caffeic acid has this effect in rats with focal cerebral ischemia [85] and in mice with brain cryoinjury [86]. Moreover, montelukast inhibits the astrocyte proliferation induced by mild ischemia-like 
injury and low concentrations of $\mathrm{LTD}_{4}$ [30]. The present study highlights the previous findings and clarifies the mode of action of endogenous CysLTs/CysLT 1 R in the critical step of glial scar formation.

In conclusion, in the present study we found that TGF- $\beta 1$-induced astrocyte migration is, at least in part, mediated by enhanced endogenous CysLTs through activating up-regulated $\mathrm{CysLT}_{1} \mathrm{R}$ (Figure 10). These findings indicate that the interaction between the cytokine TGF$\beta 1$ and pro-inflammatory mediators (CysLTs) are involved in the regulation of astrocyte function relevant to glial scar formation. However, the detailed mechanisms underlying this interaction need investigation.

\section{Abbreviations \\ 5-LOX: 5-lipoxygenase; CNS: central nervous system; CysLT, R: cysteinyl leukotriene receptor 1; CysLT R: cysteinyl leukotriene receptor 2; CysLTs: Cysteinyl leukotrienes; FBS: fetal bovine serum; GAPDH: glyceraldehyde 3-phosphate dehydrogenase; GFAP: glial fibrillary acidic protein; $\mathrm{LTD}_{4}$ : leukotriene $\mathrm{D}_{4}$; MFI: mean fluorescence intensity; NMLTC $_{4}$ : N-methyl leukotriene $C_{4}$; PBS: phosphate-buffered saline; siRNA: small interfering RNA; TGF- $\beta 1$ : transforming growth factor- $\beta 1$.}

\section{Competing interests}

The authors have no competing interests.

\section{Acknowledgments}

We thank Dr. T. Jon Seiders, Amira Pharmaceuticals Inc., USA, for supplying BAY cysLT2; Dr. John Obenhain, Merck Research Laboratories, USA, for montelukast; and Dr. IC Bruce for critically reading and revising this manuscript. This study was supported by the National Natural Science Foundation of China (81072618, 81173041, 30772561 and 30873053), the Zhejiang Provincial Natural Science Foundation (Y2090069), the Zhejiang Provincial "QianJiangRenCai Research Plan" (2010R10055), and the Fundamental Research Funds for the Central Universities (2009QNA7008).

\section{Authors' contributions}

$\mathrm{XQH}$ designed the study, performed the main parts of the experiments, analyzed the data, and prepared the manuscript. XYZ performed the immunofluorescence staining experiments and prepared the figures. XRW performed the cell migration experiments and analyzed the data. SYY performed the RT-PCR experiments and analyzed the data. SHF, YBL and WPZ contributed to the design of the study, to interpretation of the results and to the writing of the manuscript. EQW made essential contributions to the design of the study and interpretation of the results, and completed the manuscript. All authors read and approved the final manuscript.

Received: 14 January 2012 Accepted: 17 May 2012

Published: 26 June 2012

\section{References}

1. Fawcett JW, Asher RA: The glial scar and central nervous system repair. Brain Res Bull 1999, 49:377-391.

2. Saadoun S, Papadopoulos MC, Watanabe H, Yan D, Manley GT, Verkman AS: Involvement of aquaporin-4 in astroglial cell migration and glial scar formation. J Cell Sci 2005, 118:5691-5698.

3. Faber-Elman A, Lavie V, Schvartz I, Shaltiel S, Schwartz M: Vitronectin overrides a negative effect of TNF-alpha on astrocyte migration. FASEB J 1995, 9:1605-1613.

4. Striedinger K, Scemes E: Interleukin-1 beta affects calcium signaling and in vitro cell migration of astrocyte progenitors. J Neuroimmunol 2008, 196:116-123.

5. Miao H, Crabb AW, Hernandez MR, Lukas TJ: Modulation of factors affecting optic nerve head astrocyte migration. Invest Ophthalmol Vis Sci 2010, 51:4096-4103.

6. Hsieh HL, Wang HH, Wu WB, Chu PJ, Yang CM: Transforming growth factor-beta1 induces matrix metalloproteinase-9 and cell migration in astrocytes: roles of ROS-dependent ERK- and JNK-NF-kappaB pathways. J Neuroinflammation 2010, 7:88.

7. Flanders KC, Ren RF, Lippa CF: Transforming growth factor-betas in neurodegenerative disease. Prog Neurobiol 1998, 54:71-85.

8. Unsicker K, Strelau J: Functions of transforming growth factor-beta isoforms in the nervous system. Cues based on localization and experimental in vitro and in vivo evidence. Eur J Biochem 2000, 267:6972-6975.

9. Bottner M, Krieglstein K, Unsicker K: The transforming growth factor-betas: structure, signaling, and roles in nervous system development and functions. J Neurochem 2000, 75:2227-2240.

10. Massague J: How cells read TGF-beta signals. Nat Rev Mol Cell Biol 2000, 1:169-178.

11. Vivien D, Ali C: Transforming growth factor-beta signalling in brain disorders. Cytokine Growth Factor Rev 2006, 17:121-128.

12. Leivonen SK, Kahari VM: Transforming growth factor-beta signaling in cancer invasion and metastasis. Int J Cancer 2007, 121:2119-2124.

13. Pratt BM, McPherson JM: TGF-beta in the central nervous system: potential roles in ischemic injury and neurodegenerative diseases. Cytokine Growth Factor Rev 1997, 8:267-292.

14. Lehrmann E, Kiefer R, Christensen T, Toyka KV, Zimmer J, Diemer NH, Hartung HP, Finsen B: Microglia and macrophages are major sources of locally produced transforming growth factor-beta1 after transient middle cerebral artery occlusion in rats. Glia 1998, 24:437-448.

15. Ruocco A, Nicole O, Docagne F, Ali C, Chazalviel L, Komesli S, Yablonsky F, Roussel S, Mackenzie ET, Vivien D, Buisson A: A transforming growth factor-beta antagonist unmasks the neuroprotective role of this endogenous cytokine in excitotoxic and ischemic brain injury. $J$ Cereb Blood Flow Metab 1999, 19:1345-1353.

16. Samuelsson B, Dahlen SE, Lindgren JA, Rouzer CA, Serhan CN: Leukotrienes and lipoxins: structures, biosynthesis, and biological effects. Science 1987, 237:1171-1176.

17. Kanaoka Y, Boyce JA: Cysteinyl leukotrienes and their receptors: cellular distribution and function in immune and inflammatory responses. $J$ Immunol 2004, 173:1503-1510.

18. Wenzel SE: The role of leukotrienes in asthma. Prostaglandins Leukot Essent Fatty Acids 2003, 69:145-155.

19. Vannella KM, McMillan TR, Charbeneau RP, Wilke CA, Thomas PE, Toews GB, Peters-Golden M, Moore BB: Cysteinyl leukotrienes are autocrine and paracrine regulators of fibrocyte function. J Immunol 2007, 179:7883-7890.

20. Brink C, Dahlen SE, Drazen J, Evans JF, Hay DW, Nicosia S, Serhan CN, ShimizU T, Yokomizo T: International union of pharmacology XXXVII. Nomenclature for leukotriene and lipoxin receptors. Pharmacol Rev 2003, 55:195-227.

21. Rovati GE, Capra V: Cysteinyl-leukotriene receptors and cellular signals. Scientific World Journal 2007, 7:1375-1392.

22. Fang SH, Zhou Y, Chu LS, Zhang WP, Wang ML, Yu GL, Peng F, Wei EQ: Spatio-temporal expression of cysteinyl leukotriene receptor-2 mRNA in rat brain after focal cerebral ischemia. Neurosci Lett 2007, 412:78-83.

23. Zhang YJ, Zhang L, Ye YL, Fang SH, Zhou Y, Zhang WP, Lu YB, Wei EQ: Cysteinyl leukotriene receptors CysLT1 and CysLT2 are upregulated in acute neuronal injury after focal cerebral ischemia in mice. Acta Pharmacol Sin 2006, 27:1553-1560.

24. Zhou Y, Wei EQ, Fang SH, Chu LS, Wang ML, Zhang WP, Yu GL, Ye YL, Lin SC, Chen Z: Spatio-temporal properties of 5-lipoxygenase expression and activation in the brain after focal cerebral ischemia in rats. Life Sci 2006, 79:1645-1656.

25. Fang SH, Wei EQ, Zhou Y, Wang ML, Zhang WP, Yu GL, Chu LS, Chen Z: Increased expression of cysteinyl leukotriene receptor-1 in the brain mediates neuronal damage and astrogliosis after focal cerebral ischemia in rats. Neuroscience 2006, 140:969-979.

26. Zhao CZ, Zhao B, Zhang XY, Huang XQ, Shi WZ, Liu HL, Fang SH, Lu YB, Zhang WP, Tang FD, Wei EQ: Cysteinyl leukotriene receptor 2 is spatiotemporally involved in neuron injury, astrocytosis and microgliosis after focal cerebral ischemia in rats. Neuroscience 2011, 189:1-11.

27. Yu GL, Wei EQ, Zhang SH, Xu HM, Chu LS, Zhang WP, Zhang Q, Chen Z, Me $\mathrm{RH}$, Zhao MH: Montelukast, a cysteinyl leukotriene receptor-1 antagonist, dose- and time-dependently protects against focal cerebral ischemia in mice. Pharmacology 2005, 73:31-40.

28. Yu GL, Wei EQ, Wang ML, Zhang WP, Zhang SH, Weng JQ, Chu LS, Fang SH, Zhou Y, Chen Z, Zhang Q, Zhang LH: Pranlukast, a cysteinyl leukotriene 
receptor-1 antagonist, protects against chronic ischemic brain injury and inhibits the glial scar formation in mice. Brain Res 2005, 1053:116-125.

29. Ciccarelli R, D'Alimonte I, Santavenere C, D'Auro M, Ballerini P, Nargi E, Buccella S, Nicosia S, Folco G, Caciagli F, Di lorio P: Cysteinyl-leukotrienes are released from astrocytes and increase astrocyte proliferation and glial fibrillary acidic protein via cys-LT1 receptors and mitogen-activated protein kinase pathway. Eur J Neurosci 2004, 20:1514-1524.

30. Huang XJ, Zhang WP, Li CT, Shi WZ, Fang SH, Lu YB, Chen Z, Wei EQ: Activation of CysLT receptors induces astrocyte proliferation and death after oxygen-glucose deprivation. Glia 2008, 56:27-37.

31. Woszczek G, Chen LY, Nagineni S, Kern S, Barb J, Munson PJ, Logun C, Danner RL, Shelhamer JH: Leukotriene $\mathrm{D}(4)$ induces gene expression in human monocytes through cysteinyl leukotriene type I receptor. J Allergy Clin Immunol 2008, 121:215-221. e211.

32. Thivierge M, Stankova J, Rola-Pleszczynski M: Toll-like receptor agonists differentially regulate cysteinyl-leukotriene receptor 1 expression and function in human dendritic cells. J Allergy Clin Immunol 2006, 117:1155-1162.

33. Thivierge M, Stankova J, Rola-Pleszczynski M: Cysteinyl-leukotriene receptor type 1 expression and function is down-regulated during monocytederived dendritic cell maturation with zymosan: involvement of IL-10 and prostaglandins. J Immunol 2009, 183:6778-6787.

34. Kaetsu Y, Yamamoto Y, Sugihara S, Matsuura T, Igawa G, Matsubara K, Igawa O, Shigemasa C, Hisatome I: Role of cysteinyl leukotrienes in the proliferation and the migration of murine vascular smooth muscle cells in vivo and in vitro. Cardiovasc Res 2007, 76:160-166.

35. Paruchuri S, Broom O, Dib K, Sjolander A: The pro-inflammatory mediator leukotriene D4 induces phosphatidylinositol 3-kinase and Racdependent migration of intestinal epithelial cells. J Biol Chem 2005, 280:13538-13544.

36. Yuan YM, Fang SH, Qian XD, Liu LY, Xu LH, Shi WZ, Zhang LH, Lu YB, Zhang WP, Wei EQ: Leukotriene D4 stimulates the migration but not proliferation of endothelial cells mediated by the cysteinyl leukotriene cyslt(1) receptor via the extracellular signal-regulated kinase pathway. J Pharmacol Sci 2009, 109:285-292.

37. Espinosa K, Bosse Y, Stankova J, Rola-Pleszczynski M: CysLT1 receptor upregulation by TGF-beta and IL-13 is associated with bronchial smooth muscle cell proliferation in response to LTD4. J Allergy Clin Immunol 2003, 111:1032-1040.

38. Asakura T, Ishii Y, Chibana K, Fukuda T: Leukotriene D4 stimulates collagen production from myofibroblasts transformed by TGF-beta. J Allergy Clin Immunol 2004, 114:310-315.

39. Paiva LA, Maya-Monteiro CM, Bandeira-Melo C, Silva PM, El-Cheikh MC, Teodoro AJ, Borojevic R, Perez SA, Bozza PT: Interplay of cysteinyl leukotrienes and TGF-beta in the activation of hepatic stellate cells from Schistosoma mansoni granulomas. Biochim Biophys Acta 2010, 1801:1341-1348.

40. Qi LL, Fang SH, Shi WZ, Huang XQ, Zhang XY, Lu YB, Zhang WP, Wei EQ: CysLT2 receptor-mediated AQP4 up-regulation is involved in ischemiclike injury through activation of ERK and p38 MAPK in rat astrocytes. Life Sci 2011, 88:50-56.

41. Deleyrolle LP, Harding A, Cato K, Siebzehnrubl FA, Rahman M, Azari H, Olson S, Gabrielli B, Osborne G, Vescovi A, Reynolds BA: Evidence for labelretaining tumour-initiating cells in human glioblastoma. Brain 2011, 134:1331-1343.

42. Quah BJ, Parish CR: New and improved methods for measuring lymphocyte proliferation in vitro and in vivo using CFSE-like fluorescent dyes. J Immunol Methods 2012, 379:1-14.

43. Bogie JF, Stinissen P, Hellings N, Hendriks JJ: Myelin-phagocytosing macrophages modulate autoreactive T cell proliferation. J Neuroinflammation 2011, 8:85

44. Luo JY, Zhang Z, Yu SY, Zhao B, Zhao CZ, Wang XX, Fang SH, Zhang WP, Zhang LH, Wei EQ, Lu YB: Rotenone-induced changes of cysteinyl leukotriene receptor 1 expression in BV2 microglial cells. Zhejiang Da Xue Xue Bao Yi Xue Ban 2011, 40:131-138.

45. Zhang LP, Zhao CZ, Shi WZ, Qi LL, Lu YB, Zhang YM, Zhang LH, Fang SH, Bao JF, Shen JG, Wei EQ: Preparation and identification of polyclonal antibody against cysteinyl leukotriene receptor 2. Zhejiang Da Xue Xue Bao Yi Xue Ban 2009, 38:591-597.

46. Yan D, Stocco R, Sawyer N, Nesheim ME, Abramovitz M, Funk CD: Differential signaling of cysteinyl leukotrienes and a novel cysteinyl leukotriene receptor 2 (CysLT) agonist, $\mathrm{N}$-methyl-leukotriene $\mathrm{C}$, in calcium reporter and beta arrestin assays. Mol Pharmacol 2011, 79:270-278.

47. Stipursky J, Gomes FC: TGF-beta1/SMAD signaling induces astrocyte fate commitment in vitro: implications for radial glia development. Glia 2007 55:1023-1033

48. Schachtrup C, Ryu JK, Helmrick MJ, Vagena E, Galanakis DK, Degen JL, Margolis RU, Akassoglou K: Fibrinogen triggers astrocyte scar formation by promoting the availability of active TGF-beta after vascular damage. J Neurosci 2010, 30:5843-5854.

49. Lindholm D, Castren E, Kiefer R, Zafra F, Thoenen H: Transforming growth factor-beta 1 in the rat brain: increase after injury and inhibition of astrocyte proliferation. J Cell Biol 1992, 117:395-400.

50. Klaver CL, Caplan MR: Bioactive surface for neural electrodes: decreasing astrocyte proliferation via transforming growth factor-beta1. J Biomed Mater Res A 2007, 81:1011-1016.

51. Ge QF, Wei EQ, Zhang WP, Hu X, Huang XJ, Zhang L, Song Y, Ma ZQ, Chen Z, Luo JH: Activation of 5-lipoxygenase after oxygen-glucose deprivation is partly mediated via NMDA receptor in rat cortical neurons. J Neurochem 2006, 97:992-1004.

52. Li CT, Zhang WP, Lu YB, Fang SH, Yuan YM, Qi LL, Zhang LH, Huang XJ, Zhang $L$, Chen Z, Wei EQ: Oxygen-glucose deprivation activates 5lipoxygenase mediated by oxidative stress through the p38 mitogenactivated protein kinase pathway in PC12 cells. J Neurosci Res 2009, 87:991-1001.

53. Song Y, Wei EQ, Zhang WP, Ge QF, Liu JR, Wang ML, Huang XJ, Hu X, Chen $Z$ : Minocycline protects PC12 cells against NMDA-induced injury via inhibiting 5-lipoxygenase activation. Brain Res 2006, 1085:57-67.

54. Steinhilber D, Radmark O, Samuelsson B: Transforming growth factor beta upregulates 5-lipoxygenase activity during myeloid cell maturation. Proc Natl Acad Sci USA 1993, 90:5984-5988.

55. Brungs M, Radmark O, Samuelsson B, Steinhilber D: On the induction of 5-lipoxygenase expression and activity in $\mathrm{HL}-60$ cells: effects of vitamin D3, retinoic acid, DMSO and TGF beta. Biochem Biophys Res Commun 1994, 205:1572-1580.

56. Brungs M, Radmark O, Samuelsson B, Steinhilber D: Sequential induction of 5-lipoxygenase gene expression and activity in Mono Mac 6 cells by transforming growth factor beta and 1,25-dihydroxyvitamin D3. Proc Natl Acad Sci USA 1995, 92:107-111.

57. Harle D, Radmark O, Samuelsson B, Steinhilber D: Calcitriol and transforming growth factor-beta upregulate 5-lipoxygenase mRNA expression by increasing gene transcription and mRNA maturation. Eur J Biochem 1998, 254:275-281.

58. Seuter S, Sorg BL, Steinhilber D: The coding sequence mediates induction of 5-lipoxygenase expression by Smads3/4. Biochem Biophys Res Commun 2006, 348:1403-1410.

59. Ni NC, Yan D, Ballantyne LL, Barajas-Espinosa A, St Amand T, Pratt DA, Funk CD: A selective cysteinyl leukotriene receptor 2 antagonist blocks myocardial ischemia/reperfusion injury and vascular permeability in mice. J Pharmacol Exp Ther 2011, 339:768-778.

60. Carnini C, Accomazzo MR, Borroni E, Vitellaro-Zuccarello L, Durand T, Folco G, Rovati GE, Capra V, Sala A: Synthesis of cysteinyl leukotrienes in human endothelial cells: subcellular localization and autocrine signaling through the CysLT2 receptor. FASEB J 2011, 25:3519-3528.

61. Bosse Y, Thompson C, McMahon S, Dubois CM, Stankova J, Rola-Pleszczynski M: Leukotriene D4-induced, epithelial cell-derived transforming growth factor beta1 in human bronchial smooth muscle cell proliferation. Clin Exp Allergy 2008, 38:113-121.

62. Perng DW, Wu YC, Chang KT, Wu MT, Chiou YC, Su KC, Perng RP, Lee YC: Leukotriene C4 induces TGF-beta1 production in airway epithelium via p38 kinase pathway. Am J Respir Cell Mol Biol 2006, 34:101-107.

63. Eap R, Jacques E, Semlali A, Plante S, Chakir J: Cysteinyl leukotrienes regulate TGF-beta(1) and collagen production by bronchial fibroblasts obtained from asthmatic subjects. Prostaglandins Leukot Essent Fatty Acids 2012, 86:127-133.

64. Yamashita K, Gerken U, Vogel P, Hossmann K, Wiessner C: Biphasic expression of TGF-beta1 mRNA in the rat brain following permanent occlusion of the middle cerebral artery. Brain Res 1999, 836:139-145.

65. Doyle KP, Cekanaviciute E, Mamer LE, Buckwalter MS: TGFbeta signaling in the brain increases with aging and signals to astrocytes and innate immune cells in the weeks after stroke.

J Neuroinflammation 2010, 7:62. 
66. Kohta M, Kohmura E, Yamashita T: Inhibition of TGF-beta1 promotes functional recovery after spinal cord injury. Neurosci Res 2009, 65:393-401.

67. Massague J, Wotton D: Transcriptional control by the TGF-beta/Smad signaling system. EMBO J 2000, 19:1745-1754.

68. Kloos DU, Choi C, Wingender E: The TGF-beta-Smad network: introducing bioinformatic tools. Trends Genet 2002, 18:96-103.

69. Wang H, Yang GH, Bu H, Zhou Q, Guo LX, Wang SL, Ye L: Systematic analysis of the TGF-beta/Smad signalling pathway in the rhabdomyosarcoma cell line RD. Int J Exp Pathol 2003, 84:153-163.

70. ten Dijke P, Hill CS: New insights into TGF-beta-Smad signalling. Trends Biochem Sci 2004, 29:265-273.

71. Levy L, Hill CS: Smad4 dependency defines two classes of transforming growth factor beta (TGF-\{beta\}) target genes and distinguishes TGF-\{beta\}induced epithelial-mesenchymal transition from its antiproliferative and migratory responses. Mol Cell Biol 2005, 25:8108-8125.

72. Kaminska B, Wesolowska A, Danilkiewicz M: TGF beta signalling and its role in tumour pathogenesis. Acta Biochim Pol 2005, 52:329-337.

73. Finnson KW, Parker WL, Chi Y, Hoemann CD, Goldring MB, Antoniou J, Philip A: Endoglin differentially regulates TGF-beta-induced Smad2/3 and Smad1/5 signalling and its expression correlates with extracellular matrix production and cellular differentiation state in human chondrocytes. Osteoarthr Cartil 2010, 18:1518-1527.

74. Chen $M, L v Z$, Jiang $S$ : The effects of triptolide on airway remodelling and transforming growth factor-beta/Smad signalling pathway in ovalbuminsensitized mice. Immunology 2011, 132:376-384.

75. Lampropoulos P, Zizi-Sermpetzoglou A, Rizos S, Kostakis A, Nikiteas N, Papavassiliou AG: TGF-beta signalling in colon carcinogenesis. Cancer Lett 2012, 314:1-7.

76. Park BJ, Park Jl, Byun DS, Park JH, Chi SG: Mitogenic conversion of transforming growth factor-beta1 effect by oncogenic Ha-Ras-induced activation of the mitogen-activated protein kinase signaling pathway in human prostate cancer. Cancer Res 2000, 60:3031-3038.

77. Dai C, Yang J, Liu Y: Transforming growth factor-beta1 potentiates renal tubular epithelial cell death by a mechanism independent of Smad signaling. J Biol Chem 2003, 278:12537-12545.

78. Kim YK: TGF-beta1 induction of p21WAF1/cip1 requires Smadindependent protein kinase C signaling pathway. Arch Pharm Res 2007, 30:739-742.

79. Niculescu-Duvaz I, Phanish MK, Colville-Nash P, Dockrell ME: The TGFbeta1induced fibronectin in human renal proximal tubular epithelial cells is p38 MAP kinase dependent and Smad independent. Nephron Exp Nephrol 2007, 105:e108-e116.

80. Kane NM, Jones M, Brosens JJ, Kelly RW, Saunders PT, Critchley HO: TGFbeta1 attenuates expression of prolactin and IGFBP-1 in decidualized endometrial stromal cells by both SMAD-dependent and SMADindependent pathways. PLOS One 2010, 5:e12970.

81. Watkins SJ, Borthwick GM, Oakenfull R, Robson A, Arthur HM: Angiotensin II-induced cardiomyocyte hypertrophy in vitro is TAK1-dependent and Smad2/3-independent. Hypertens Res 2012, 35:393-398.

82. Gomes FC, Sousa Vde O, Romao L: Emerging roles for TGF-beta1 in nervous system development. Int J Dev Neurosci 2005, 23:413-424.

83. Buss A, Pech K, Kakulas BA, Martin D, Schoenen J, Noth J, Brook GA: TGFbeta1 and TGF-beta2 expression after traumatic human spinal cord injury. Spinal Cord 2008, 46:364-371.

84. Komuta $Y$, Teng $X$, Yanagisawa H, Sango K, Kawamura K, Kawano H: Expression of transforming growth factor-beta receptors in meningeal fibroblasts of the injured mouse brain. Cell Mol Neurobiol 2010, 30:101-111.

85. Zhou Y, Fang SH, Ye YL, Chu LS, Zhang WP, Wang ML, Wei EQ: Caffeic acid ameliorates early and delayed brain injuries after focal cerebral ischemia in rats. Acta Pharmacol Sin 2006, 27:1103-1110.

86. Zhang L, Zhang WP, Chen KD, Qian XD, Fang SH, Wei EQ: Caffeic acid attenuates neuronal damage, astrogliosis and glial scar formation in mouse brain with cryoinjury. Life Sci 2007, 80:530-537.

doi:10.1186/1742-2094-9-145

Cite this article as: Huang et al:: Transforming growth factor $\beta 1$-induced astrocyte migration is mediated in part by activating 5 -lipoxygenase and cysteinyl leukotriene receptor 1. Journal of Neuroinflammation 2012 9:145.

\section{Submit your next manuscript to BioMed Central and take full advantage of:}

- Convenient online submission

- Thorough peer review

- No space constraints or color figure charges

- Immediate publication on acceptance

- Inclusion in PubMed, CAS, Scopus and Google Scholar

- Research which is freely available for redistribution 